\title{
THE ROLE OF LIBRARIES IN PROMOTING ADULT EDUCATION
}

\author{
Irena Zemaitaityte \\ Mykolas Romeris University, Lithuania
}

\begin{abstract}
The article discusses the function of the library in the changing society and educational activity among elderly citizens. The growing number of elderly people in a society requires permanent revision and adaptation to the new conditions of education, social security, economy, health protection areas. Today the function of the library is seen as a multifunctional institution for education, leisure, culture, information and recreation. Modern library through participation in many programmes and projects provide elderly people with training in computer and digital skills, and functional literacy. Participation in library events enhances activity, engagement, participation in society`s life of the elderly.
\end{abstract}

Keywords: older adults, education activities, libraries.

\section{Introduction}

Ageing of population and the consequences of this phenomenon create challenges that draw researchers' attention worldwide. The Lithuanian National Programme took the consideration of the problem: "Though many a measure is implemented for provision of active personal, public, professional and cultural lives for senior citizens, these measures do not meet all the required alterations for the welfare of the elderly completely, therefore, there still remains the need to combine efforts to build environment in which the elderly would live active personal, public, professional and cultural life" (National Programme for 2012 European Year for Active Ageing and Solidarity between Generations, 2012).

One of the positive developments in the current period in Lithuania is the growing number of organizations and institutions, which provide adult education, senior adult education, cultural activities and a wide spectrum of services (Zemaitaityte, 2012). Today the key measure in the state policy for the elderly is the adoption of the National Strategy of Overcoming Consequences of Ageing. The National Strategy indicates that: "One of the goals of the national culture is to provide the society and every member of this society, also older people, with the possibilities to take part in cultural life, to choose the preferred leisure activities and to find ways for self-expression." (2004, p. 23). With regard to this goal every year the budget of the Republic of Lithuania provides support to culture and art projects and programmes, and municipalities give platform for the amateur production and local community outputs. The 
important role is assigned to libraries, which are active in dealing with social exclusion, employability, education and lifelong learning issues of adults and take steps in providing conditions for their active cultural lives. Lithuanian Seimas, on reviewing the function of the libraries: authors nights, book discussions, meetings with the writers, promoting young writers, growing libraries` depositories, and taking into account the immense value of these functions for the development of the society and for the education of the national spirit and culture announced 2016 the Year of Library.

The paper seeks to discuss the role of libraries in the development of adult education in Lithuania, the ways older people engage themselves with these activities; the challenges that libraries meet in providing these educational activities.

\section{The concept and the function of the library}

Traditional library (Greek word Bibliotheke - biblion - means book, the ke- storing place) is a selection or a collection of properly indexed, systemically aligned books. Oxford dictionary (2007) defines a library as "a building or room containing collections of books, periodicals, and sometimes films and recorded music for use or borrowing by the public". In the Law of the Libraries of the Republic of Lithuania of 2013, a library is defined as a juridical person founded in accordance with the existing laws and regulations and acting as such in the dissemination of information, culture, science and education areas and performing the functions of a library or a structural part of a juridical person empowered to act as a library. Jovaiša (2007) defines library as "a cultural and educational institution who stores books, periodicals and other publications, provides for the informational needs of the readers as well as for their scientific, technical, artistic interests, and organises educational activities. It is also an institution for developing a social individual" (Jovaiša, 2007, p. 38).

The key functions of the library are assembling, classification and storing of books, manuscripts and periodicals; these are broadly acknowledged functions of preserving humanity`s memory. Modern definitions stress social and communicative (public dissemination of news, information and documents) character of the library (Mizzi, 2008; Reardon, 2011). Petuchovaite (2004) lists five key areas that received the most attention in the recent functioning of the libraries:

1) development of information society, embracing information technologies, internet and data bases access, services for the target user groups;

2) development of the educational and training activities as a provision for lifelong learning; 
3) development of culture, cultivating traditions in ethnography, museum, book and reading, and publishing functions;

4) social inclusion and community building development, targeted community building services, integration initiatives of disabled groups and other socially challenged groups, fostering of civic education;

5) provision for leisure activities, services for organising events and festivities.

One of the main goals of the library is to disseminate information and knowledge in the collaborative attempt to advance the society intellectually, economically, socially and culturally. Library as a critical actor in organising information, culture and recreation activities, it promotes open and active society. Library rests on the socially contracted principles of dissemination and preservation of culture and scientific information obtained by the humanity in its historical growth. Recent technological transformations caused by the globalisation did not abort these tasks but, in reality, enhanced the potential of the libraries to take part in building economic and social welfare. Lithuanian Seimas, on reviewing the function of the libraries: authors' nights, book discussions, meetings with the writers, promoting young writers, growing libraries` depositories supplies, and taking into account the immense value of these functions for the development of the society and for the education of the national spirit and culture announced 2016 the Year of Library.

The system of Lithuanian libraries consists of: Lithuanian national library, district public libraries, municipality public libraries, research and educational institutional libraries, school libraries (with the exception of higher educational institutions), special libraries and other libraries (Law of the Libraries of the Republic of Lithuania, 2013). Researchers remark that public library type is much newer than research, national, university or school library types. While document storing and preservation for the coming generations, providing for the intellectual and cultural continuity are among the foremost national, research and academic libraries' goals, the public libraries, in the opinion of the researcher, aim at dissemination of knowledge, information, culture and experience for the end users, and for free access to all. Therefore, the mission of the public library is to guarantee free access to information and news for all members of the society, to promote democratic, free and open society (Glosiene et al., 1998).

Today library functions as a complex society oriented institution of education, leisure, culture, information and recreation. To provide full access to information resources the libraries have to network both locally and on a broader scale for internalising and developing technologies of information search and processing. Therefore, a library in its modern mission, in its function and mode of operation is a hybrid social institution, open and responsive to the changing 
needs of the society and sensitive to its own internal transformations. As noticed by Kirtikliene (2008), the library function is influenced not only by the Lithuanian laws and programmes alone but also by the modifications in the model of the developing society and in habits of life. To meet the new goals for the library it is far from suffice to have a library per se with full depositories and to remain passive until someone will make avail of those. From the institution that stays passive and its function in society is rather lateral, the library turns into an active player on the social scale (Evans \& Ward, 2003; Petuchovaite, 2004).

Though library traditions are set and they are observed, library development indicates that the capacity to change with the changing society needs, market situation and, in particular, with the new technologies is indispensable condition for the library existence. As is stated by researchers (Petuchovaitè, 2004; Lamanauskienè, 2006), the fundamental modernisation is a principal condition for advance development and for effective cooperation with local self-governing bodies. Partnership of successful libraries includes partner cooperation with local self-governing institutions and participation in the networks of other institutions and individuals. Lithuanian public library system connects 60 municipality public libraries with 1340 branch libraries and five district libraries (Statistikos Departamentas, 2014). Administration of the libraries is handed over to local municipalities` and this allows developing decentralised management of libraries. This situation causes greater diversity of library services and roles, conditioned by the library potential and by the community interests (Senkus, 2007). The strengthening of public relations allow to maintain adequate relations with all stakeholder groups, to provide an actual image of the library activities and possibilities, to respond to the requirements of the organisations and enterprises.

One of the key goals of the modern library is client satisfaction. The key attention directed towards the end user is indicative of the general trend of societal development. The end user may come to the library guided by many informational needs. The individual seeks to issue a book or find some literature on a certain topic, to deal with some indistinct informational need and at the same time the individual might pick a book for a weekend, review an exhibition, use computer or just list through the newspapers. Library employees familiar with their social, economic and cultural environment are apt to construct different library function areas (Kirtikliene,, 2008). UNESCO Manifesto of Public Libraries (1994) stresses that constructive cooperation and democratic growth depends on education, open and limitless opportunities to gain knowledge, free use of information and cultural assets.

Current moment in history for the librarians has become a critical revision period for the library`s mission, functional upgrading and for the identification 
of their own niche in the ever changing society. The modifications in academic function, science integration, development of science and technologies, speedy growth of information and communication technologies, dominating input of the market are the main reasons for initiation of the change of traditional libraries (Duobinienè et al., 2004).

\section{Library assisted adult education}

An adult individual guided by the need to know comes to a library as to an institution of informal education with the intention to develop intellectual and creative powers, planning for wider social acclaim, denser communication, selfrealisation. This adult individual seeks to learn because his learning goals are shaped by self-education. Self-education, as a most individualised cognitive activity, develops an all-sided, harmonious personality and helps in one`s societal establishment (Tight, 2007; Žemaitaitytè, 2012). However, Lithuania is still dominated by the valuation of education which provides formal qualification supported by some sort of diploma, while education which is based on an individual initiative of the learner and related to the cultural and personal development often is not regarded as education at all. M. Teresevičienès (1999) states "we tend to ignore or not to regard as educational activities and, consequently, not to collect statistical data about education leading to individual development and based on the individual initiative of the citizens and, clearly, contributing to the growth of lifelong learning" (Teresevičienè, 1999, p. 115). Thus, learning may take place outside specially geared educational environment (educational and learning institutions), it may happen in the environment other than educational: in libraries, culture institutions, non-educational institutions, open areas. As is marked by Longworth (2007, p. 119), "culture institutions, museums, art galleries and libraries adapting to the Lifelong Learning age requirements undergo stunning transformations". N. Longworth (2007) indicates that three crucial factors that motivate adults to learn are easy acceptance, secure environment, positive assessment of the possessed skills and abilities, and the excitement to continue studies. All this, without doubt, adults find under the roof of a library.

It is important to draw attention to the fact that libraries are often seen as participating in the education which is interpreted and analysed as functional literacy development - both in children and in adults, and as promotion of reading. Traditionally literacy was seen as individual ability to write, read and show numerical skill, and it was associated with school and education. However, recent decades brought up the strand of New Literacy, when literacy is interpreted as a multiple phenomenon, its social and functional aspects are particularly stressed, i.e. literacy is seen as the individual capacity to carry out 
writing tasks in the attempt to perform certain social functions in the community (Tamošiūnaite, 2013). In A. Wagner`s \& R. Kozma`s (2005) view literacy in information society indicates that apart from the understanding of a text, one needs to use information communication technologies for the information search, analysis, evaluation and apply all for dealing with problems and in construction of new knowledge. This gives ground for the appearance of the information literacy term, which is most often identified as "an ability to find, assess and apply different information, ability to learn, understand and know the ways of storing information" (Glosienè, 2006, p. 186). Researchers (Feist \& McDougall, 2013; Watering, 2006) highlight multiple effects of new technologies on humanity: they are related to the developing of material and spiritual values, social and cultural environment.

Researchers (Mockus et al., 2013; Miežytė-Tijūšienè \& Bulotaitè, 2012) stress that social activity as a form of active life contributes to the wellbeing of an elderly individual. Scientific research data show that social activity and inclusion is very useful to elderly people since they diminish risks of mortality, boost daily function, may assist in protecting and maintaining psychic health. In A. Mockus' view (2013, p. 342), "educational and social activity group interventions directed towards specific groups may reduce social exclusion and solitude among elderly people". Interpersonal relations and engagement into activities are very important social factors in building life satisfaction in elderly people. A. Samenas (1995) remarks that educating the readers, forming and developing a reader's individuality, supporting effectiveness of reading are joint library and readers activities. The society in its appreciation of the information and communication, seeks to involve more citizens in the function of a library, and to develop quality readers. Though a library alone is not capable to deal with this task (not all citizens are readers at the library), yet, in the opinion of A. Samenas (1995) libraries make the strongest part in the development of the readers, since they dispose of the richest resources and opportunities to impact upon the reading contents and manner; they are also the place for informal communication. To let an individual feel independent, active, responsible citizen and enjoy the individual growth, have better professional career opportunities an individual requires informational communication competence and functional literacy skills. However, one of the modern demographic crises features is diverse digital literacy levels among citizen groups (Selwyn et al., 2014).

By announcing 2012 a European Year for Active Ageing and Solidarity between Generations European Commission directed attention to the global societal ageing phenomenon and its consequences. European Commission encouraged European Union member countries to look deeper into global societal ageing and approach it as an area of untapped societal resources. By promoting activity of the elderly people through their engagement and 
involvement in the life of society and enhancing their opportunities of independent life their input into society is emphasised; elderly citizens can take an active part in the life of the society and establish links between generations. These goals are observed by supporting elderly people`s functional literacy on the European Union level and on the national level. Through implementation of different programmes and projects the elderly people acquire opportunities to augment their computer skills, numerical abilities and stretch their functional literacy, their activity, engagement; participation in societal life is supported.

The opportunity to use information technologies and the required information competencies should not depend on gender, age, income no place of residence, however, Universal Computer Literacy Survey carried out in 2009 in Lithuania showed that an average computer user in the country is a young, educated, employed citizen with an income larger than average. (Kalvaitis, 2009). Computer was not used or seldom bussed by an elder, mostly retired citizen. The Survey showed that functional literacy of the elder people in Lithuania is rather low (Kalvaitis, 2009).

More recent research indicates improvement of this situation. According to the Department of Statistics data in 2011 in Lithuania 63 percent of citizens aged 16-74 used computers, in the age group 65-74 years old 12 percent of citizens were able to use computer; in 2013 almost 69 percent of citizens aged 16-74 used computer. In 2013, 15.1 percent in the age group of 65-74 years old used computer (Informacinestechnologijos, 2013). This positive tendency in Lithuania appeared, among other factors, due to the project "Libraries for the Progress" which was implemented according to the international tripartite agreement among the Ministry of Culture of the Republic of Lithuania, Lithuanian National MartynasMažvydas Library and Bill and Melinda Gates Foundation. By supporting and applying to use the resources of public libraries it was aimed to motivate Lithuanian citizens to have better library access and to use different information technologies. Within several years Lithuanian public libraries developed into institutions that take active part in dealing with citizens' digital exclusion. 1276 public libraries participated in the project "Libraries for the Progress", among these the central public libraries, rural and urban public libraries and their subdivisions took part. 891 libraries out of the total number were supplied with technical equipment for the public internet access stations and for other electronic services provision (Bibliotekospažangai, 2012). Almost over the whole territory of the country (cities and rural territories) citizens gained physical access to computers and internet. Individuals who do not possess a computer or have no access to the Internet at home can find a free public access point to such technology within a distance of $5-7 \mathrm{~km}$ on the premises of a library. In the attempt to equal off the unevenness of the infrastructure and to give the population equal IT access a large portion of 
computers and other technical equipment was stored in the libraries. This projected activity gave results, in 2011 technical divide between urban and rural libraries practically disappeared. 52 percent of rural area libraries participating in the project "Libraries for the Progress" provided public internet in 2008, in 2011 the number of such libraries grew to reach 97 percent (Bibliotekospažangai, 2012). Internet users in rural libraries made avail of Internet services more often. In 2009 rural public library branches provided free Internet services to about 20 percent of the users; in 2011 this number grew to 28 percent. Urban libraries, which in their majority could use public Internet access before the project, also showed a considerable though numerically smaller growth from 88 to 99 percent (Bibliotekospažangai, 2012). A marked change was brought into library work by the participation of librarians in the training courses and following computer literacy (information, digital etc.) trainings for Lithuanian citizens organised in Lithuanian libraries. In 2009 for providing in-service librarian training a network of training centres involving qualified professionals consulted users on a daily basis for the development of digital skills and their upgrading both in the urban and rural areas. 11 centres opened 222 study places, half of these were mobile. Library employees after taking digital literacy courses organised by these centres called computer skills courses for the library users themselves. In total, 2700 library employees took part in the courses organised by the project "Libraries for the Progress", over 75 thousands citizens took part in the library courses organised by the librarians. In 2011 library digital literary courses were attended by a number of disabled, unemployed and rural dwellers 4 times exceeding the previous years, the number of retired people exceeded previous number 5 times (Bibliotekospažangai, 2012). In some places, making avail of mobile computer classes, the courses were organised outside library premises, for example relocating them into the rural community premises. However, the significance of the project for librarians and for the library users did not lay solely in the technological equipment provided and installed by the project "Libraries for the Project" implementation activities. No less significant is the fact that the project activities involved updating and modernising many library structures (Bibliotekospažangai, 2012).

In 2014 the project "Libraries for the Project 2" team and Lithuanian National MartynasMažvydas Library (Kokybinis bibliotekų vaidmens pokyčio tyrimas, 2014) carried out a quantitative research into library function change. For the research purposes library directors and project coordinators were interviewed. The results showed how the library role, status and place in society have changed over the period of 5 to 10 years: the change stretches from the location where the books are issued to a multifunctional complex with diverse activities. In discussion about the future of the library two broad areas of change 
were identified - changes following the societal alterations, i.e. library as an institution responds to the common and group interests; and library as an educational and training institution, in that case library will change at a greater speed than the whole society and the social environment.

\section{Conclusions}

By way of concluding, we may point to the emerging new model of the library as a multifunctional complex. Within the context of the societal transformation the key mission of the library and its functional priorities refurbish themselves, the function of the provision of information and digital literacy surfaces to the top addressing the needs of elderly people, in particular. These changes are determined by the society experiencing changes life needs. Within the context of radical changes in society and in the field of information services libraries are searching for the new models of function and structure to match the scope of needs of the end users and to put technology to quality service provision. Most importantly libraries develop into guarantors of democracy in the information society, and of free information and knowledge access and dissemination.

\section{References}

Bibliotekos pažangai. (2012) Downloaded from: http://www.bibliotekospazangai.lt/lt/ informacines-technologijos/informaciniu-technologiju-pristatymas

Duobinienė, G., Kretavičienė, M., Štremeikis, A., \& Tautkevičienè, G. (2004). Akademinès bibliotekos kaita: informacijos greitkelio link. Lietuvos bibliotekininku kongresas. Downloaded from: http://www.lbd.lt/reng/gene.ppt

Evans, E. G., \& Ward, P. L. (2003). Beyond the basics: the management guide for library and information professionals. N. Y.-London: Neal-Schuman publishers.

Feist, H., \& McDougall, K. (2013). Older people's use of new communication technologies: Research Findings \& Policy Implications. Australian Population \& Migration Research Centre Policy Brief. Vol. 1, No. 8. Adelaide, South Australia: The University of Adelaide. Downloaded from: http://www.adelaide.edu.au/apmrc/

Glosienè, A. (2006). Akademinès bendruomenès informacinès kompetencijos ugdymas: po dvidešimties metu. Knygotyra, Nr. 47, 186-202.Vilnius: Vilniaus universiteto leidykla.

Glosiene, A., Petuchovaite, R., \& Raceviciute, R. (1998). Viešoji biblioteka: tradicija ir modernumas: Mokomoji knyga. Vilnius: Žara.

Johannsen, C. G., \& Pors, N. O. (2005). Pokyčiu ir kokybès valdymas bibliotekose. Klaipėda: Klaipèdos universiteto leidykla.

Jovaiša, L. (2007). Enciklopedinis Edukologijos žodynas. Vilnius: Gimtasis žodis.

Kalvaitis, A. (2009). Visuotinio kompiuterinio raštingumo tyrimas. Vilnius: Lietuvos suaugusiujų švietimo ir informavimo centras.

Kirtikliene, D. (2008). Viešosios bibliotekos vaidmuo visuomeneje. Magistro darbas. Vilnius: Vilniaus universitetas. 
Kokybinis biblioteku vaidmens pokyčio tyrimas. (2014). Downloaded from: http://www.bibliotekospazangai.lt/lt/poveikio-vertinimo-tyrimai/2-as-pokyciuvertinimas

Lamanauskienè, (2006). Akademine biblioteka studiju procese. Šiauliai: Šiaulių universiteto leidykla.

Lietuvos Respublikos Biblioteku Istatymas. (2013). Downloaded from: http://www3.lrs.lt/pls/inter3/dokpaieska.showdoc_1?p_id=464213\&p_tr2=2

Longworth, N. (2007). Mokymosi visa gyvenima praktika: Švietimo kaita XXI amžiuje. Vilnius: Kronta.

Miežytė-Tijūšienė, J., \& Bulotaitè, L. (2012). Pensinio amžiaus žmonių socialinis aktyvumas bei psichologinè savijauta. Gerontologija, Nr. 13 (4), 199-205.

Mizzi, R. (2008). The Role of Libraries in Promoting reading and Literacy. Conference on Book Reading in Malta. Downloaded from: http://www.malia-malta.org/ presentations.html

Mockus, A., Sondaitė, J., \& Butėnaitė, J. (2013). Socialiai aktyvių vyresnio amžiaus žmoniu pasitenkinimo gyvenimu psichosocialinių veiksnių kokybinè analizė. Socialinis darbas, Nr. 12 (2), 340-352.

Nacionalinė 2012-ujų Europos vyresnio amžiaus žmonių aktyvumo ir kartų solidarumo metų programa. (2012). Downloaded from: https://www.e-tar.lt/portal/forms/legalAct.html? documentId=TAR.B0F07BD2FA4B

Oxford dictionary. (2007). Oxford: Oxford University Press.

Petuchovaitè, R. (2004). Viešuju biblioteku paslaugų bendruomenei plètra: sékmingos praktikos Lietuvoje ir tarptautiniu veiksniu studija. Vilnius: Vilniaus universiteto

Reardon, S. (2011). The Free Public Librar'y Role in Education. Philadelphia Social Innovations Journal 36.

Samėnas, A. (1995). Skaitytoju ugdymo samprata. Teoriniai bibliotekininkystès pagrindai. Vilnius: STL, 197-200.

Selwyn, N., Gorard, S., Furlong, J., \& Madden, L. (2003). Older Adults' Use of Information and Communications Technology in Everyday Life. Ageing \& Society. 23, 561-582.

Senkus, A. (2007). Lietuvosbibliotekos 2006 metais. Tarp knygu, Nr. 6, 1-7.

Informacinèstechnologijos Lietuvoje. (2013). Vilnius: Lietuvos statistikos departamentas.

Statistikos departamentas. (2014). Rodikliu duomenu baze. Downloaded from: http://db1.stat.gov.lt/statbank/

Tamošiūnaitè, A. (2013). Raštingumo link: keli sociolingvistiniai XX a. pradžios lietuvių išeiviu portretai. Oikos 2 (16), 59-74.

Teresevičienè, M. (1999). Populiarusis suaugusiuju Švietimas: individuali iniciatyva ar socialinis reiškinys? Socialinè - psichologinè adaptacija ir švietimo sistema. Kaunas: Vytauto Didžiojo universitetas.

The National Strategy To Overcome Ageing Consequences. (2004). Downloaded from: http://www.monitoringris.org/documents/strat_nat/Strategy_LTU_en.pdf

Tight, M. (2007). Kertinès suaugusiuju švietimo ir mokymo idejos. Vilnius: Kronta.

UNESCO Public Library Manifesto. (1994). Downloaded from: http://www.unesco.org/ webworld/libraries/manifestos/libraman.html

Wagner, D. A., \& Kozma, R. (2005). New Technologies for Literacy and Adult Education: A Global Perspective. UNESCO: UNESCO Publishing. Downloaded from: http://www.literacy.org/sites/literacy.org/files/publications/Wagner_Lit-

ICT_UNESCO_05.pdf 
Proceedings of the International Scientific Conference. Volume IV, May $27^{\text {th }}-28^{\text {th }}$, 2016. 193-203

Watering, M. (2006). The Impact of Computer Technology on the Elderly. Amsterdam: VrijeUniversiteit.

Žemaitaitytè, I. (2012). Non-governmental organizations' initiatives working with the older people. Intergenerational solidarity and older adults education in community: Ljubljana: Faculty of Arts at the University of Ljubljana, 272-279. 